Portland State University

PDXScholar

2016

\title{
Trust \& Growth in the Workplace: an Analysis of Leadership in Flat Organizations
}

Drake George

Portland State University

Follow this and additional works at: https://pdxscholar.library.pdx.edu/honorstheses Let us know how access to this document benefits you.

\section{Recommended Citation}

George, Drake, "Trust \& Growth in the Workplace: an Analysis of Leadership in Flat Organizations" (2016). University Honors Theses. Paper 353.

https://doi.org/10.15760/honors.341

This Thesis is brought to you for free and open access. It has been accepted for inclusion in University Honors Theses by an authorized administrator of PDXScholar. Please contact us if we can make this document more accessible: pdxscholar@pdx.edu. 


\author{
Drake George \\ Trust \& Growth in the Workplace: \\ An Analysis of Leadership in Flat Organizations \\ Honors Thesis, Portland State University
}

\begin{abstract}
Management styles affect the overall performance of employees and the growth of a business. Intertwined with leadership are the concepts of trust and credibility in relation to the success of a business and the satisfaction of employees and customers. A leader's ability to adapt their management style to forecast changes in their industry strengthens their command of the business, and can establish trust. The overall challenge of transparency is that it is multifaceted. Trust from employees to leadership, trust from leadership to employees and trust from consumer to business all play a large role in establishing honest business practices. Through an in depth literature review, I have explored the importance of trust in the workplace. Aspects such as growth and employees satisfaction were identified as supporting concepts. The results show a strong correlation between trust, encouragement and growth of employees when evaluating over leadership success.
\end{abstract}

Keywords: Flat Organizations, Credibility, Transparency, Trust, Leadership, Growth, Management, Organizational Structure 


\section{Introduction}

Over the course of my research, I looked at management in the workplace and the need for leadership styles that vary depending on industry, business size, employee needs and ongoing growth. Research was conducted while maintaining the overlying topic of trust and credibility, and the need for all small organizations to uphold a higher standard for honesty and transparency. I focused my research on small organizations who have seen rapid growth post 2008. An emphasis on small businesses was targeted as $68 \%$ of spending at these locations is reinvested back into the local community (Sutter, 2016).

Flat organizations are structures with minimal to no middle management, often empowering employees to take on more responsibility (Ingram, 2009). Small businesses vary by industry, but many identify as flat organizations. Some may choose that structure, others may not even know they have a specific structure (such as small family businesses.) Due to an increased demand for options outside of a corporate world, the trend of small, local businesses have caught the attention of consumers (Marcial, 2016). The intention of buying from small businesses varies by both geographical location and the general demographics, which help businesses to define consumers. Some may seek to grow their local economy, others may desire to be trendy, and some may seek the best options for themselves and their family (Hart, 2010).

Leadership is a core function to a successful small business. Management who practice effective leadership styles can prepare for unforeseen changes and adapt to a variety of employees. In some cases, the necessity for management specific titles may not exist, but that does not mean leadership simply fails to exist. Individuals on a team or staff often times pinpoint 

FLAT ORGANIZATIONS

a team lead depending on a variety of skill sets. Some may perceive knowledge and understanding as the ideal leader. Others may identify a leader who is quick and concise.

The overall growth of small, flat organizations can be dependent on trust and credibility in the workplace. Small businesses compete with established brands who occupy large portions of the market. In order to grow, they must offer a product or service that serves a niche market. Additionally, for said small businesses to grow, the roots of the business, including employees and management must uphold transparency and credibility. This works in each direction, for example; the overall flat organization must be credible to the consumer, the employees must trust their leadership team, and trust must be upheld in the employees (Covey, 2006). Flat organizations become dependent on trust in the workplace to keep them afloat as they often operate on tight budgets and have strict timelines to uphold (Tenner, 2014).

In my own experience as an intern with three different flat organizations over the past three years, I found four universal themes that occurred when addressing trust and credibility. The first theme is the balance between familial relationships in a flat organization; these types of familial relationships can greatly impact the style of communication between leadership and employees, therefore often blurring the line of professionalism. The second theme is that trust in an organization heavily depends on the role leadership takes on, that their true character is known by employees, and that they must embody maintain a transparent persona. The third theme is that employees who are dedicated to growing with an organization and are highly motivated to improve, although they may not always receive enough feedback due to the operation of a flat organization. The fourth and final theme is that structure in a flat organization is still needed in some form; structure allows an organization to remain transparent in times of hardship. 


\section{Background}

Leadership at any level should be knowledgeable regarding various management styles. Leadership must constantly be adapting to their environment, including expansion of size, new staff, changes in the market, etc. When looking at a business's long-term success, management must seek out the best style suited for the scope of work and employees they oversee. With recent growth in the flat business market, credibility and trust are key drivers for businesses to be successful (Covey, 2006). With determination to adapt during change, transparency allows a flat organization to uphold an image, which can define their success (Schenk, 2016).

When shopping locally, roughly $68 \%$ of spending is invested back into the local economy (Sutter, 2016). A key driver of the small business market is a consensus in the nontraditional city favoring small businesses over large corporations (Wolk, 2014). A shift of management styles has begun to influence the operations of small businesses. When looking at the role management plays in these businesses, research showed that it was a trend to operate with minimal structure in flat organizations (Devine, 2015). Middle management is lessened and employees are given more authority over the work they do.

Trust in employees must be maintained in order to continue an autonomous work environment. In these markets, familiar terms associated with small start-ups are organic, open space and employee driven (Kiger, 2006). Many new business owners are taught that being entirely open and structure free is the best management style for small business (Sutter, 2016). In reality, to be scalable, flat organizations must adapt a management practice that maintains some form of structure and control while still trusting employees (Kohler, 2015). Addressing 

FLAT ORGANIZATIONS

professionalism and the role it plays in flat organizations plays a large role in what structure and control looks like in the workplace (Devine, 2015).

The research and observational studies contained are addressed to small business owners in regions similar to the Portland Metro business market. The research is applicable to leadership who are facing business growth while needing to constantly change and adapt their management style. This research is geared towards the themes of transparency, honesty and credibility as they apply to flat organizations. The overall impacts of trust and credibility are discussed throughout the literature review in its applicability to flat organizations.

\section{Methodology}

An in depth literature review was conducted to determine common themes inside the scope of flat organizations in regards to trust and credibility. With the use of two written texts and a variety of online peer reviewed articles, a compilation of research was established.

The articles utilized are all post 2006, written prior to the economic recession in the year 2008 , and in post recovery in the years after. The method of selecting articles was defined by analyzing articles that had a significant focus on transparency, credibility, and trust in flat organizations. These texts looked at aspects of business downsizing and growth, the marketing of products and services as well as the differences between small and large organizations. All the articles touched on the need, for or lack thereof, of trust in a work environment.

Two selected texts were chosen for research in regards to credibility and trust in the workplace. First, The Speed of Trust by Stephen Covey (2006) focuses on trust and the role it plays at work and in work-based relationships. By exploring relationships and the importance credibility plays when examining superiors, and how leaders must be consistent in their transparency, this text was an ideal fit for my research. The second text, The Leadership 

FLAT ORGANIZATIONS

Challenge by Kouzes \& Posner (2002) provides an in-depth look at various aspects of being a leader. Through discussion of leadership styles, recognition, organizational alignment and goal setting, this text provided insight on leadership as a whole.

\section{Literature Review}

The following concepts discussed are themes that emerged during the course of my research. The topics of trust and credibility are focused on in relation to the concepts and the influence on flat organizational growth. The discourse contained in this section can be utilized to evaluate small businesses and the functionality of current management strategies.

\section{Organizational Structures}

The overall structure of organizations often determines what type of management style is possible to practice effectively (Lavoie, 2015). Businesses who operate under a flat structure may face challenges pertaining to their leadership dynamic. Flat organizations are defined as "structures featuring less layers of management. In flat organizational structures, employees are empowered and expected to take responsibility for a range of traditionally managerial decisions in their daily routines" (Ingram, 2009).

A challenge facing management in flat organizations is their span of control. Span of control is defined as the scope of involvement an individual or an organization has in regards to ongoing projects or a team they oversee (Pilon, 2015). Leadership in flat organizations often

find themselves pulled toward assisting their staff and overseeing all aspects of production. The motivation behind managers is a dedication to the organization and the desire to help all employees find success (Blasingame, 2016). Often times, the practice of a traditional management style is associated with micromanaging (Canner, 2016). The practice of micromanaging can have adverse effects on trust in the organization. Micromanagement can 


\section{FLAT ORGANIZATIONS}

cause slow production, frustration in employees, and a gap in the trust between staff and

leadership (Canner, 2016). Positive intention is not enough to make micromanaging effective, there must be recognition of staff needs from management's perspective.

Flat organizations are often noted to be family like in their relationships. Familial relationships are defined as having few boundaries in terms of professionalism, with an increased sense of trust, and transparency (Dattner, 2011). These staffs are small, work closely together and typically have fewer boundaries than in a large-scale organization (Hamel, 2011). Employees are typically involved in every aspect of production creating a dynamic that leads to trust and dependability between all parties. This organizational structure has the advantage of being adaptable to change due to the small size. If everyone in the staff upholds trust these organizations can overcome large changes while maintaining a transparent environment (Ingram, 2009). Additionally, these organizations face restrictions in their limited resources (England, 2015). The growth of an organization is dependent on finances, staffing ability and scalability in the practiced management style to accommodate growth. With limited resources, businesses may find challenges in growth of the organization as well as relationships. With close-knit staff, growth can cause growing pains in relation to trust with staff leaving, new staff onboarding and a transitional growth period (Hamel, 2011).

\section{Leadership Styles}

It is prudent to review ten of the most common leadership theories that have evolved over time. Each offers different strengths and weaknesses to an organization. The theories have components of each, which can be applied in current flat organizational structures, in terms of trust, credibility and adaptability in organizations. In figure 1 we see a chart that contains an overview displaying ten common leadership theories. 


\section{Leadership Theories}

\begin{tabular}{|c|c|}
\hline $\begin{array}{l}\text { The Great Man } \\
\text { Theory }\end{array}$ & $\begin{array}{l}\text { The theory that you leaders are born and not made. This is not the only } \\
\text { way to become a leader, but some may have more natural leadership } \\
\text { ability. }\end{array}$ \\
\hline $\begin{array}{l}\text { The Trait } \\
\text { Theory }\end{array}$ & $\begin{array}{l}\text { Focused on which characteristic we should seek out and become better } \\
\text { with in order to become a leader. By identifying traits, people could learn } \\
\text { to be a certain way to perform better. }\end{array}$ \\
\hline $\begin{array}{l}\text { The Skills } \\
\text { Theory }\end{array}$ & $\begin{array}{l}\text { Focused on practical skills versus qualities of a leader to achieve. You } \\
\text { need people skills to interact with others and conceptual skills to see the } \\
\text { big picture. }\end{array}$ \\
\hline $\begin{array}{l}\text { The Style } \\
\text { Theory }\end{array}$ & $\begin{array}{l}\text { This theory looks at styles such as democratic, autocratic, laissez faire. } \\
\text { This theory looks at the need to be people friendly but also demand } \\
\text { performance in a consistent manner }\end{array}$ \\
\hline $\begin{array}{l}\text { The Situational } \\
\text { Theory }\end{array}$ & $\begin{array}{l}\text { The theory argues that no one leadership fits every employee. It looks at } \\
\text { a variety of skills and characteristics and their applicability depending on } \\
\text { the staff and the organizational size. }\end{array}$ \\
\hline $\begin{array}{l}\text { The } \\
\text { Contingency } \\
\text { Theory }\end{array}$ & $\begin{array}{l}\text { This theory looks at the leader and determines if they are the right fit for } \\
\text { the situation. Effective leadership is contingent on matching a leader's } \\
\text { style to the setting. This means finding the right leader to match that of } \\
\text { the employees they oversee. }\end{array}$ \\
\hline $\begin{array}{l}\text { Transactional } \\
\text { Theory }\end{array}$ & $\begin{array}{l}\text { This theory looks at people's will to follow based off the action of a } \\
\text { leader. So the leader's job is to find the right mix of rewards and } \\
\text { punishments in order to closely monitor what is happening. }\end{array}$ \\
\hline $\begin{array}{l}\text { Transformationa } \\
1 \text { Theory }\end{array}$ & $\begin{array}{l}\text { This theory looks at the importance of encouragement in situations } \\
\text { versus the give and take approach of transactional leadership. This } \\
\text { theory drives results by a leader's ability to transform the environment } \\
\text { employees are in. }\end{array}$ \\
\hline $\begin{array}{l}\text { Leader-Member } \\
\text { Exchange } \\
\text { Theory }\end{array}$ & $\begin{array}{l}\text { This theory states that there is an exchange between employee and } \\
\text { leader. This theory states that there is a group a leader favors and one } \\
\text { they do not. The end goal of the theory is to eliminate these groups and } \\
\text { their division }\end{array}$ \\
\hline $\begin{array}{l}\text { Servant } \\
\text { Leadership } \\
\text { Theory }\end{array}$ & $\begin{array}{l}\text { This theory suggests that the more emphasis a leader places in helping } \\
\text { others and fulfilling their needs, the more trust is created. This theory } \\
\text { emphasizes the need for a leader to be available and accessible to } \\
\text { employees. }\end{array}$ \\
\hline
\end{tabular}



FLAT ORGANIZATIONS

Figure 1. This is a chart displaying ten leadership theories by time progression of origin (Zigarelli, 2013).

While these theories vary in their developmental effectiveness, it is important for leaders to evaluate their leadership style as it applies to building trust in an organization to assist it in its potential growth. While there are various leadership styles, I will primarily reference autocratic leadership and servant leadership because they are polarized. Autocratic leadership is looked upon as sole control from the top; “Autocratic leadership, also known as authoritarian leadership, is a leadership style characterized by individual control over all decisions and little input from group members. Autocratic leaders typically make choices based on their ideas and judgments and rarely accept advice from followers" (Cherry, 2016). Servant Leadership is described as a person with a desire to serve others. They commit to bettering those they are around and go the extra mile to make sure everyone succeeds (Prichard, 2013).

\section{Efficiency \& Effectiveness}

Businesses often refer to success in terms of financial profit versus loss. This is considered a business's bottom line. Efficiency is described as the following "performing or functioning in the best possible manner with the least waste of time and effort; having and using requisite knowledge, skill, and industry; competent; capable" (Zaziji, 2012). Managers strive to be efficient in their abilities, a common management style cited as inefficient is micromanaging. Micromanaging is often practiced with good intent; in order to ensure the best possible quality of product is being delivered (Barnes, 2015). This process often lengthens out the productivity time and can negatively reflect on the credibility of a business and their employees.

Effectiveness is described as "adequate to accomplish a purpose; producing the intended or expected result" (Sococco, 2010, para. 1). Management can often measure the success of their management style in correlation to trust and transparency. This includes looking at overall 

FLAT ORGANIZATIONS

productivity rates, surveying staff on their experience (under said management style) and monitoring their day-to-day practices. By doing so, a leader who is transparent opens the door for feedback and pursues desired changes. A leader must be familiar with a business environment, engaging their peers, earning respect based off of their actions and having command of the subject matter they work with (Stark, 2011). Being an effective leader means picking the management style that is most applicable to one's staff and ensuring that method is monitored for any potential changes. While being effective and efficient, a leader must remember to not cut corners, maintaining their pathway of credibility during every step of their business matters (Hamel, 2011).

A leader's ability to be efficient and effective can largely depend on the industry they work in. In order to be an efficient and effective leader, one must take the time to learn about the wants and needs of the staff they oversee (Stark, 2011). If the management style does not align with employee needs there is the potential for employees becoming disgruntled. Additionally, efficiency and effectiveness create trust in the workplace by creating a leader who is alert and aware of their surroundings. These leaders have the ability to foresee change and help their staff adapt when necessary.

The question then arises, how efficient and effective is it to be a micromanager? There is no right or wrong answer; the answer lies in the situation itself. Leaders must be capable of examining when their input is becoming debilitating to staff, and when it is negatively affecting a staff's ability to perform (Barnes, 2015). For example, leaders must determine if their staff trusts management. Management must be willing to take a step back and ask themselves the same question. 

FLAT ORGANIZATIONS

If leaders trust their staff, then why feel the need to be a part of every step in the process? By determining how a leader's input is affecting a staff, a leader can change the way they oversee others in order to create a more trusting space. A leader may also find that at certain points their presence is desired, and at other points they must relinquish some control in order to empower staff (Barnes, 2015). Maintaining trust, encouraging and empowering employees and stepping in when help is requested are all starting points for leadership teams to become efficient and effective. Efficiency and effectiveness are not only reflections on employees, but also on how management delegates tasks and assigns their time to daily operations.

\section{Scalability}

Scalability in reference to rapid growth of an organization plays a large role in the adaptation of a management style. There has been a $49 \%$ increase in small businesses over the last 20 years; such increase has affected overall competition on all types of businesses (ElNajjar, 2016). Scalability is relevant as it looks at a flat organization's ability to expand, whether that means hiring more employees, opening new locations in the same city, opening new locations in other cities or taking on more upper management. In order to see any growth, a business must be credible, consumers must think highly of an organization and their ethics in order to fully support their products or services (Devine, 2015).

Scalability and rapid growth are intertwined, by emphasizing the importance of transparency; leadership can adapt their management style to lead employees by example in the pursuit of growth (Kiger, 2016). When looking at a small business's ability to grow in size or number of locations, management must determine staff needs. Businesses that find themselves restricted due to inadequate resources may also consider evaluating their management team and the level of overall employee's satisfaction (England, 2015). Looking at the management style 

FLAT ORGANIZATIONS

utilized, leadership must determine if it encourages staff to be independent and take pride in their work. Leadership styles that promote self management tend to benefit from employees feeling a sense of urgency when producing quality work, but also upholding a strong ethical position, feeding into reciprocal trust and credibility (Lavoie, 2015).

Scalability also plays a large role in team dynamics and how they change as small businesses grow rapidly. Businesses that do not have a plan for growth in place prior to rapid expansion are likely to face many growing pains (Pavkovic, 2016). This includes a change in team dynamics. As mentioned, tight knit teams in business are often referred to as families. This scenario is often applied to small sized staffs that have faced a variety of change while often maintaining the same owners and or manager. These teams grow together and often take on familial relationships, with a transparent dynamic (Hamel, 2011). Due to these relationship developments, there tends to be an increase of interdependency and trust.

When rapid growth takes place in teams, there are a few areas of considerations for management. First, rapid growth can mean increased employee numbers and new management. This can easily change the dynamic of team, making some feel displaced and others may lose faith in the organization (Flamholtz, 2016). If new management is taken on, there is a new authority figure for staff to report to. This person may be brand new to the organization, potentially angering some staff, as promotion from within is common in small businesses (Blasingame, 2016). Additionally, rapid growth can mean an increase in sales or an increase in clients.

Working with clientele is a part of many service industries. When new clients are taken on, a division of work must occur in order for businesses to complete a project. When staff are paid based off of the project they work with, jealousy may arise when high profile client projects 

FLAT ORGANIZATIONS

are assigned to some but not to others (Flamholtz, 2016). In contrast, employees who work with high profile clients may see no change in pay. This can lead to the questioning of fair workload balance and the under-appreciation of staffing. The work a staff does must be reinforced by a leader's ability to identify proper forms of praise, dependent on the employee's needs and the company's resources (Kiger, 2006).

\section{Team Dynamics}

Although we have discussed how small organizations may find themselves with a very familial dynamic, team dynamics may change when a new personality is added to the mix. The result can be positive or negative depending on the current ability of staff to adapt (Lavoie, 2015). There are several key areas to consider in a team dynamic when facing rapid growth. The boundaries between staff members in a close-knit staff may change due to expansion. Leadership may be involved less in certain areas which may reduce the overall structure of the organization. The scope to which leadership oversees may also change in regards to their physical ability to monitor a growing staff (Webb, 2016).

Depending on the business itself, professionalism will look different in most organizations. Professionalism can be present across a wide spectrum depending on the organization one works for and the expectations that have been set. Professionalism can range from appearance such as acceptable work attire; to the way staff interact with one another, to the language used inside a workspace. This plays an integral role in the dynamic of small businesses and the relationships that are created. Leadership may have close relationships with their staff, they may be seen as friends first, and may not recognize the authority figure role (Blasingame, 2016). The key problem that stems from this is a misinterpretation of boundaries. Unless certain actions or language are deemed unacceptable in the workplace, employees have no structure that 

FLAT ORGANIZATIONS

expectation has been set on. This falls on the shoulders of management to set the tone for the environment they work in (Webb, 2016).

With an increase in locations, moving into a larger space or the acquiring of more staff, leadership's role may be reduced in certain areas. If employees have become dependent on leadership's influence on certain components of work, a transitional period will occur from staff (Blasingame, 2016). This should be monitored closely to ensure staff does not feel abandoned or as though their workload has become overwhelming. The loss of an effective leader may have negative consequences on a business, thus when staff is shuffled from one location to another, they may struggle to perform on the same level (Lavoie, 2015).

A team's dynamic often lies in a balance of finding the right staff members, transitioning others and finding a leader who can speak to everyone while upholding the morals of the majority (Olguin, 2013). As businesses grow this task becomes more challenging. Often businesses find themselves more compelled to hire out of necessity rather than taking diligent time in the hiring process. The outcome may bring on a staff member who excels socially and fits right in with the staff. On the other hand, a new staff member may not fit well with the already established team dynamic (Kohler, 2015). Growth in an organization affects the intake of staff, the transition of management and leadership from one location to the next, and the overall ability to recruit a fluid staff that are proficient themselves at relating to other staff members (Webb, 2016).

\section{Motivations \& Determination}

Employees and employers all come to work for various reasons. We often take a surface look of the motivations of individuals, resulting in the idea that money and status are the only drivers of employees. Employees seek motivation in many forms, largely encouragement 

FLAT ORGANIZATIONS

through traditional and innovative methods (Bell, 2015). Employers who are willing to adapt their management strategy and recognize the different motivators their employees desire can successfully motivate outside of fiscal promises. Determination plays a role in these motivators. Determination is an essential component of what drives employees and employers to come to work in good and bad times (Flamholtz, 2016).

Determination at its root is often what pushes a staff through a challenging project, an economic time of hardship and the growing pains of a business's expansion. Determination for leadership may come in the form of seeking to expand the employee base due to increased demand (Bell, 2015). Determined employees may find success in flat organizations, but they may also grow frustrated with the limited business resources. In these situations, communication about employee and business needs is crucial to ensuring staff members have a similar understanding of where the business is headed (Devine, 2015). Additionally, while looking at the overall growth behind flat organizations, the motivation must come from all components of a business. Without having credibility and transparency between staff and leadership, gaining traction for growth will prove to be difficult (Bell, 2015).

For employers, business owners and management, determination and motivators may be the same as employees. But they may also vary due to an increased dedication to the organization (Marcial, 2015). Leadership may face hardships and the burden of financial instability, industry fluctuation and employee satisfaction. Additionally, they may fall into a routine of keeping their business alive without reflecting on areas of change, seeking growth in ways other than in the size of their business (Devine, 2015). Employers can find motivation and determination in terms of growing their management style to benefits their employees. They may also find motivation in changing their style of recognition (Kouzes \& Posner, 2002). When 


\section{FLAT ORGANIZATIONS}

employees display their gratitude and appreciation for being recognized, leadership can use this as an opportunity to become more credible among their employees (Flamholtz, 2016).

Motivation and determination can drive commitment to an organization. They may have adverse effects, as commitment may lead to a narrow span of thinking (Marcial, 2015). Innovation must be encouraged from employees, and leadership must be willing to implement new ideas to generate new processes. Without an innovated creative process, motivation and determination will be halted (Flamholtz, 2016). By trusting employees in their decision-making, leadership can strengthen the overall trust in their organization. This can be outwardly reflected on consumers of products and services, as unhappy employees reflect negatively on an organization. But employees with a passion for their organization provide a transparent face for the organization (Kouzes \& Posner, 2002).

\section{Discussion \& Conclusion}

The goal of this literature review was to discover what areas of business practices are influenced by trust and credibility. Furthermore, uncovering what impacts trust and credibility has on core themes in business functions. To reiterate, flat organizations retain minimal management, they reduce middle management and focus on employee engagement simply through the structure of the organization. The influence that the structure type has on a business will greatly impact the dynamics of each business function. With an analysis of flat organizations, my investigation was on the basis that employee engagement has the potential to be high due to the structure.

One of my key findings was that there is no sole management practice that can be used as a blanket for all businesses. Due to differences in structure, geographical location, size, industry, etc. management styles must constantly be observed, examined and modified when necessary. 

FLAT ORGANIZATIONS

Secondly, trust and credibility act as cornerstones for success in business. From the perspective of consumers trusting an organization, the trust employees uphold in their management, to management entrusting their employees. Trust is a component that drives relationships in all aspects of business. Credibility plays a similar role, as it demonstrates the amount of trust individuals will put into people or organizations. Third, trust and credibility greatly impact the potential for growth of flat organizations. As stated previously, trust and credibility play a role in the eyes of consumers, but also influence employees of an organization's. Employees must trust their leadership team in order to let down their guard and fully commit to an organization's values.

The relevance of trust and credibility in the workplace is ever rising. Our current economic climate has begun to push consumers in the direction of local, organic, natural, and healthy, etc. With that in mind, organizations have found a niche market for offering desire products and services. The importance of being transparent could prove to be a vital component of their success as large corporation push back, and communities question the authenticity of small organization values. Transparency of business practices is an essential component of employee retention and brand image.

The most key themes discussed in the literature review are Organizational Structures, Leadership Styles, Efficiency \& Effectiveness, Scalability, Team Dynamics and Motivations \& Determination. The general impacts businesses face when seeking growth or reevaluation of management styles most pertained to the common core themes. These areas aided on perspective of trust and credibility, but alluded to the overarching theme of transparency and honesty as additional terms of reference that flat organizations should emphasize in their operations.

\section{Limitations \& Further Research}



FLAT ORGANIZATIONS

An initial limitation to my literature review was that research on flat organizations was not well defined to a single industry. Without the ability to focus in on a specific industry, I was unable to qualitatively analyze industry specific findings. By not breaking my findings down by industry, I was unable to identify if the scope of management styles was more applicable depending on a specific industry.

Secondly, one area I had to recognize began with my initial thesis focus. Initially, I had the understanding that there was one blanket management style that worked for everyone in all industries. Through the developmental process of my thesis, I was able to identify my bias and preconceived notion of management practices. By reevaluating my thesis question, I allowed myself the opportunity to consistently monitor the effect of my bias on my research. This was also a limitation as it was a challenge of influence from a style I wanted to focus on, versus allowing the literature review point me in the direction of a conclusion.

If I were to conduct further research, I would compose a preliminary survey, focused on flat organizations. In order to identify gaps in my literature review, a survey would provide the opportunity to generate conversations around the common themes I identified. Inside of those themes, focusing on questions that would either confirm or deny my findings, to further challenge my research and the scope in which I conducted it.

Additionally, I would conduct interviews with employees of more than one flat organization. I would utilize businesses in different industries, for example, marketing, finance, medical, law, etc. This would allow the perspective of various types of businesses versus solely focusing on an organic or traditional industry. In these interviews I would focus on questions regarding the identified themes above in order to receive more conclusive quantitative data. A 

FLAT ORGANIZATIONS

key factor would be interviewing leadership in these organizations as well. Identifying the role they believe they play and the management style they utilize.

\section{References}

Barnes, L. (2015, March 31). Damaging Effects of Micromanagement. Retrieved November 10, 2016, from http://patimes.org/damaging-effects-micromanagement/

Bell, A. (2015, September 25). 5 Ways to Motivate Staff in a Small Business. Retrieved October 07, 2016, from http://www.investopedia.com/articles/personal-finance/092515/5-waysmotivate-staff-small-business.asp

Blasingame, J. (2016, November 19). Small Business Ethics. Retrieved November 20, 2016, from https://www.smallbusinessadvocate.com/motivational-minutes/small-businessethics-22

Canner, N. (2016, August 17). Why Is Micromanagement So Infectious? Retrieved November 21, 2016, from https://hbr.org/2016/08/why-is-micromanagement-so-infectious

Cherry, K. (2016, June 22). What Is Autocratic Leadership? Retrieved November 17, 2016, from https://www.verywell.com/what-is-autocratic-leadership-2795314

Covey, S. M., \& Merrill, R. R. (2006). The speed of trust: The one thing that changes everything. New York: Free Press.

Dattner, B. (2011, April 26). Re-enacting family dynamics in the workplace. Retrieved November 22, 2016, from https://www.psychologytoday.com/blog/credit-and-blamework/201104/re-enacting-family-dynamics-in-the-workplace 


\section{FLAT ORGANIZATIONS}

Devine, T. (2015, October 22). How to Choose a Business Structure With Minimum Risk (and Maximum Reward). Retrieved November 27, 2016, from http://www.inc.com/teddevine/how-your-business-structure-affects-your-risk-exposure.html

El-Najjar, A. (2016, July 19). Portland Small Business. Retrieved November 27, 2016, from https://townsquared.com/blog/2016/07/portland-small-business/

England, A. (2015, November 30). Small Business? Limited Resources? GOOD. Retrieved October 02, 2016, from http://centerlyne.com/small-business-limited-resources-good/

Flamholtz, E. (2016, March 22). Growing Pains in Small Business. Retrieved November 27, 2016, from https://www.thebalance.com/growing-pains-in-small-business-1200437

Hamel, G. (2011, December). First, Let's Fire All the Managers. Retrieved November 11, 2016, from https://hbr.org/2011/12/first-lets-fire-all-the-managers

Hart, G. (2010, January 27). Buy local: Trendy movement offers across the board value.

Retrieved October 13, 2016, from http://www.dailyprogress.com/orangenews/news/buylocal-trendy-movement-offers-across-the-board-value/article_19a008a5-3a09-53028974-889327b9d1b0.html

Ingram, D. (2009). Business Models \& Organizational Structure Flat Organizational Structure The Advantages of Flat Organizational Structure. Retrieved November 20, 2016, from http://smallbusiness.chron.com/advantages-flat-organizational-structure-3797.html

Kiger, P. (2006, March 09). Hidden Hierarchies. Retrieved November 20, 2016, from http://www.workforce.com/2006/03/09/hidden-hierarchies/

Kohler, M. J. (2015, April 15). How to Choose the Right Business Structure. Retrieved November 27, 2016, from https://www.entrepreneur.com/article/244190

Kouzes, J. M., \& Posner, B. Z. (2002). The Leadership Challenge. San Francisco: Jossey-Bass. 


\section{FLAT ORGANIZATIONS}

Lavoie, A. (2015, June 02). 4 Considerations When Determining the Best Leadership Structure for Your Business. Retrieved November 27, 2016, from https://www.entrepreneur.com/article/246770

Marcial, G. (2015, May 6). Why Small Businesses Are Becoming More Cloud Conscious. Retrieved November 03, 2016, from http://www.forbes.com/sites/genemarcial/2015/05/06/why-small-businesses-arebecoming-more-cloud-conscious/\#3bd6b8467ae2

Olguin, M. A. (2013, February 05). Build a Winning Team Dynamic. Retrieved November 27, 2016, from http://www.inc.com/michael-olguin/build-a-winning-team-dynamic.html Pavkovic, 12 April 2016 | The Agile Blogosphere, L. (2016, April 16). 4 Stages Of High Performing Teams. Retrieved November 27, 2016, from http://www.allaboutagile.com/4-stages-of-high-performing-teams/

Pilon, A. (2015, July 19). Multitasking Isn’t Always the Best Idea for Business Owners. Retrieved November 20, 2016, from https://smallbiztrends.com/2015/07/multitaskingin-business.html

Prichard, S. (2013, January 24). 9 Qualities of Servant Leadership. Retrieved October 07, 2016, from http://www.skipprichard.com/9-qualities-of-the-servant-leader/

Schenk, L. (2016, October 15). Top 10 Reasons Why Most New Businesses Will Fail. Retrieved November 27, 2016, from http://www.virtuallinda.com/branding-and-strategy/top-10reasons-why-most-new-businesses-will-fail/

Sococco, D. (2010, May 13). Effective Vs. Efficient: Do You Know The Difference? Retrieved October 5, 2016, from http://www.dailyblogtips.com/effective-vs-efficient-difference/ 


\section{FLAT ORGANIZATIONS}

Stark, P. B. (2011, November 23). What is Transparent Leadership? Retrieved September 12, 2016, from https://www.peterstark.com/transparent-leadership-2/

Sutter, B. (2016, May 06). All Business. Retrieved November 27, 2016, from https://www.allbusiness.com/15-facts-small-businesses-owners-want-you-to-know103312-1.html

Tenner, D. (2014, September 9). Flat hierarchies, mentorship and personal development. Retrieved October 28, 2016, from https://danieltenner.com/2014/09/09/flat-hierarchymentorship-personal-development

Webb, C. (2016, February). How small shifts in leadership can transform your team dynamic. Retrieved November 27, 2016, from http://www.mckinsey.com/businessfunctions/organization/our-insights/how-small-shifts-in-leadership-can-transform-yourteam-dynamic

Wolk, D. (2014, October 15). Why Portland, Oregon, Is Such an Amazing Small-Business Incubator. Retrieved November 27, 2016, from http://www.slate.com/articles/business/buy_a_small_business/2014/10/small_business_i n_portland_oregon_it_s_a_fantastic_place_to_set_up_or_buy.html

Zaziji, M. (Director). (2012, February 28). Rethinking the Structure of Corporations [Video file]. In TedTalks. Retrieved September 23, 2016, from https://youtu.be/8eRwOM9iqVo

Zigarelli, M. (2013, August 17). Retrieved November 27, 2016, from https://www.youtube.com/watch?v=XKUPDUDOBVo 